Bond University

Research Repository

\title{
Pedagogical sustainability of a rural school and its relationship with community
}

Kinash, Shelley; Hoffman, Michelle

Published in:

Rural Society

DOI:

10.5172/rsj.19.3.229

Licence:

Other

Link to output in Bond University research repository.

Recommended citation(APA):

Kinash, S., \& Hoffman, M. (2009). Pedagogical sustainability of a rural school and its relationship with community. Rural Society, 19(3), 229-240. https://doi.org/10.5172/rsj.19.3.229

\section{General rights}

Copyright and moral rights for the publications made accessible in the public portal are retained by the authors and/or other copyright owners and it is a condition of accessing publications that users recognise and abide by the legal requirements associated with these rights.

For more information, or if you believe that this document breaches copyright, please contact the Bond University research repository coordinator. 


\section{Bond University}

\section{ePublications@bond}

2009

\section{Pedagogical sustainability of a rural school and its relationship with community}

Shelley Kinash

Bond University, shelley.kinash@gmail.com

Michelle Hoffman

Follow this and additional works at: http://epublications.bond.edu.au/hss_pubs

Part of the Educational Assessment, Evaluation, and Research Commons

\section{Recommended Citation}

Shelley Kinash and Michelle Hoffman. (2009) "Pedagogical sustainability of a rural school and its relationship with community" Rural society, 19 (3) , 229-240.

http://epublications.bond.edu.au/hss_pubs/366 


\title{
Pedagogical sustainability of a rural school and its relationship with community
}

\author{
Shelley Kinash and Michelle Hoffman
}

\begin{abstract}
This article presents and analyses a single pedagogic case of a small, rural primary state school in Queensland, Australia. The researchers spent one day per week for nineteen weeks serving the role of visiting teachers to the school. The goal of the research was to inquire into the pedagogical sustainability of this rural school and its relationship with community. Data was interpreted through Kilpatrick, Johns, \& Mulford's (2003b) school-community partnership framework. The key research finding was that the impacts of school-community partnership initiated through an inquiry-based teaching and learning project extended beyond the scope and longevity of the project, thereby predicting pedagogical sustainability.
\end{abstract}

Keywords: Case study; Small, Rural primary school; Pedagogical sustainability; Schoolcommunity partnership

Received 14 October 2008 Accepted 10 March 2009

Dr. Shelley Kinash is an Assistant Professor of Higher Education at Bond University. She was a Visiting Academic from the University of Calgary in Canada to the University of Southern Queensland in Australia when the research was conducted. This research has ignited Shelley's passion for rural schooling, particularly through school-community partnership.

Michelle Hoffman is an Education Student at the University of Southern Queensland. She is a long-term advocate of rural school-community partnership, being a rural community member and active school committee member.

Corresponding author: Dr Shelley Kinash email address: skinash@bond.edu.au Postal address: Bond University, Gold Coast, Queensland 4229.

\section{Introduction}

Rural schooling is recognised by some as a vital component of Australian culture. In a speech to the Australian Labour Party National Conference in 2007, Stephen Smith, Minister for Foreign Affairs, identified rural schooling as a government priority. Kilpatrick, Johns and Mulford's (2003a) research emphasised the importance of community connectedness to rural schools and their survival. Kilpatrick, Johns, Mulford, Falk, and Prescott (2002) indicated that sustaining schools in rural contexts builds capacity in these communities, both at a systematic level including economic 
development, and at the level of personal empowerment. Rural schooling is important to the sustainability of rural community.

Research has also indicated that rural schooling has positive consequences for students. Yang and Fetsch (2007) demonstrated that rural children have equal self-esteem, if not higher, compared to urban children. Reeves and Bylund's (2005) empirical research indicated that rural children's academic achievements are equal to, or better than, their urban counterparts.

Despite acknowledgement of rural schools as a significant and important Australian resource, the sustainability of rural schooling is problematic. Analysis of a school closures spreadsheet released by the Queensland Department of Education, Training and the Arts revealed that since 2003 an average of two rural schools have closed per year. Miller (2008) reported the threat of closure of the Ramsay, Queensland school. The article reported that Ramsay is a 127-year-old school with a current enrolment of ten students from prep through to year seven. There are multiple quotations throughout the article from community members naming the school as the 'heart' of the community. The article closes with the statement, 'We aren't just talking about our school here, we are talking about saving our unique community - we can't let them throw away our history.' ABC Brisbane (2008) reported the potential closure of Ropeley and Junction View state schools, where there is a combined enrolment of 18 students. The article stated that the 'Education Department is basing their closure decision on the 'region's growth,' 'travelling distance to other schools,' and most applicable in the context of this article, 'community service obligations.' In other words, one of the factors that might contribute to the sustainability of small, rural schools is the maturity of the school-community partnership (Kilpatrick, et al., 2003b).

Morgan and Blackmore's (2007) research identified some of the vulnerabilities of rural schooling as, 'demographic trends (ageing population; declining birth rate and changing farming practices) and the vagaries of climate, now exacerbated in the twenty-first century, which can spell prosperity or ruin' (p. 2). The authors wrote that parents are choosing to educate their children outside of their rural communities due to the misconception that bigger and private is better. Thereby, another threat to rural school sustainability is public perception. Jones (2004) interpreted his statistical analysis to mean that Australian children enrolled in private urban schools have a significant academic and social advantage over those children who are not. It is this dominant discourse of rural disadvantage that is challenged through this empirical research into teaching and learning and relationship with community of a small, rural school in southeast Queensland.

\section{Literature Review}

We conducted the literature search through EBSCOhost MegaFILE Premier which includes: Academic Search Premier; EJS-E-Journals; ERIC, and; Professional Development Collection. The search specifications were: research manuscripts; scholarly (peer-reviewed) journals; 2000-2008 publication year; search terms - rural and primary school. One hundred eleven documents emerged in the results list. Of these 111, eight 
were multiple listings of the same article and three were unrelated. Of the remaining 100 articles, only eight addressed non-pathological issues in rural primary schooling. Examples of non-pathological topics included: continuing professional development, home-tutoring, and creative thinking facilitated through information and communications technologies. Examples of pathological topics in rural primary schooling included: malnourishment, obesity, poverty, parasitic infection, depression and HIV/AIDS. Applying a reflexive research stance, this literature review clearly indicates reporting and construction of rural communities as pathological.

In addition to sorting the results into the categories of pathological and non-pathological, results were clustered into the country identified by the situated research. The countries identified by the largest number of research studies in the domain of rural primary schooling were South Africa (13), Australia (10), United Kingdom (9), Kenya (8), and Tanzania (8). The countries of Greece, Guatemala, Mexico, and Turkey were each cited in four articles. Three articles were situated in each of the countries of Botswana, China, Ireland, and Pakistan. Two articles identified each of the countries of India, Indonesia, Mozambique, Uganda, Sri Lanka, and Taiwan. Finally, one article situated the research on rural primary schooling in each of Afghanistan, Cambodia, Côte-d'Ivoire, Fiji, Lithuania, Nigeria, Palestine, Philippines, Trinidad/Tobago, and Zambia. While the international and multi-cultural representation yielded through this literature search is affirming, there is also a notable absence.

There is a paucity of literature situated in a non-pathological stance on rural schooling in economically developed countries. In other words, the resounding view perpetuated by the existent literature is that rural schools are a poor second cousin to urban schools. Further, the families enrolling their children in rural schools are problematised. The literature conveys the erroneous impression that families enrol their children in rural schools out of necessity rather than informed choice, and perpetuates the equally fallacious interpretation that the children are victims of poverty, malnutrition, and underdevelopment. This article seeks to contribute a challenging voice to this dominant discourse. The pedagogic case study described in this article presents an exemplar primary school environment, in large part defined by its relationship with community through an intentional rural context.

\section{The Inquiry}

This article presents a deep inquiry into the day-to-day experiences of the children, staff, and greater community of a single small, rural school in Queensland, Australia. This particular school was chosen for three reasons. First, the school met the inquiry characteristics of being small and rural. Second, the principal and teachers were keen to participate. Third, the school is in close proximity to the research university and was thus convenient for the necessary time commitment of phenomenological research.

The 2008 student enrolment was thirty-two children, across two mixed-age classrooms. Thirteen children were enrolled in a Prep through Year Four class, and nineteen children in Year Five through Seven. Two teachers job-shared a position with the younger students. The principal was the primary teacher for the older class. The school also had 
one full-time and three part-time instructional aides. With the exception of one family with two children, the families all live in the local community, with farming as the primary occupation. The school is within a half-hour drive of an urban centre. Indicators of 2009 enrolment predicted a downsizing to a one-room school with mixed age from Prep through Year Seven. The unanimous perception of the school staff and Parents and Citizens' Council members is that the primary factor impacting upon the forecasted downsizing is the ageing of the local families. Given the proximity to the urban centre, the primary enrolment-boosting strategy is increasing the perceived school territory through advertising the virtues of small, rural schooling.

The notable feature of the chosen school is its pastoral environment. Located in a valley, the schoolyard is framed by mountains. A wide variety of trees including seasonably colourful jacarandas and grevellias draw plentiful bird-life including lorikeets, galahs, whip-birds, and wagtails. A possum has made the top of an air conditioning unit her home. Horses grazing in the adjoining fields stretch their necks over the fence for a scratch from the children. The children play in a well-equipped playground and numerous fields and other sports facilities including a tennis court and cricket pitch.

As researchers, we spent every Friday from 8:30am to 3pm at the school for nineteen weeks. We served as participant observers, supporting the children as researchers. Alongside the principal and teachers, we helped the children organise into four mixedage groups, frame their own research questions, derive their own data collection strategies including planning excursions, and present their findings using various educational technologies. We had multiple roles including tutors, storytellers, and excursion chaperones.

The question pursued in this research is whether a school-university partnership had a substantive and lasting impact on the teaching and learning, community connection, and continuance of this small, rural school. The methodological approach was grounded in van Manen's (1997, 2002) hermeneutic phenomenology. This research methodology seeks to observe and understand the meaning of day-to-day experience. As researchers, we documented our observations and impressions, sought to capture the voice of the children, their teachers and the broader community in the school context, and interpreted the meaning of these phenomena. The in-depth inquiry is what matters about this research. As the enrolment in this school is declining (threatening its very continuance), and the status of small, rural Queensland schools is jeopardised overall (Queensland Department of Education, Training and the Arts, n.d.), it is incumbent upon educational researchers to inquire into the role and function of these schools.

While some educational stakeholders will find resonance with the setting, context, and themes of this inquiry, the intention is not to frame this school as representative of all small, rural schools. This research inquires deeply into the day-to-day experience of these particular children in this particular school, thereby radiating meaning outward for those readers who wish to apply interpretations to their own contexts. In other words, the goal of this research was to inquire into why this one school matters, and thereby initiate reflection with respect to the significance of other small, rural, primary schools. 
We collected data using five means. First, we explicitly enrolled the children as researchers. We introduced them to the research method of phenomenology, as described by researchers such as Alvesson and Sköldberg (2000), and Moustakas (1994). We distributed a set of eight digital still cameras on multiple occasions, giving each child plenty of time with their own camera. On one occasion, we asked them to take pictures of their spaces and tools of learning. On other occasions they took photographs of their excursions. We interpreted the photographs one-on-one with the children and through focus groups. Throughout the process, we engaged the children in meta-reflections with respect to what it means to be a researcher.

The second means of gathering data was through field notes, using the methods of Emerson, Fretz, and Shaw (1995). The topics of our field notes included the students, teachers, school environment, community and its members, and project experiences. We used mixed-methods in composing our notes. Sometimes we recorded our observations, impressions, and interpretations individually and then emailed them to one another. Other times we engaged in pedagogic conversation, and then wrote our field notes either individually or collaboratively. At times our field notes were very close in content and interpretation. More frequently, we discovered that alternate phenomena proved salient to each of us, and/or that we had contrasting, and thus illuminating interpretations of the same phenomena.

The third means of data collection was through digital videography. Throughout our research with the children, we documented the process through digital video. Three alternate photographers captured the video. First, one or the other of us operated the video camera. Second, the children operated the video cameras, to give us a close approximation of perception through their lenses. Third, the Media Services department of our affiliated university professionally videoed all of the excursions and special events. Video capture served as a multi-sensory memory of the research, and facilitated multimedia dissemination of our results (Kinash \& Crichton, 2007).

Fourth, we collected data through conducting interactive interviews with the children, parents, school staff, and members of the community. Researchers such as Berg (1995), Ellis, Kiesinger, and Tillman-Healy (1997), Marshall and Rossman (1989), and Spradley (1979) define interactive interviews as a conversation with a specific informationgathering purpose. Thematic subjects loosely guided the interviews. However, as interviewers, we followed the interviewees' lead, asked open-ended questions, and mutually exchanged information and affective perceptions. In some instances, one of us conducted one-on-one interviews, and other times we interviewed in pairs or small groups. Respondents were interviewed more than once as the research project progressed, and as we noted indicators of perceptual change.

Fifth, we accumulated research data through collecting artefacts. For example, we interpreted the children's progress on their technological productions, such as various stages of their podcasts. We gathered samples of their artwork, and narrative writing. We collected media clippings with respect to the project, and emails exchanged between the 
school personnel and us. In addition, we collected artefacts that revealed aspects of the community such as Education Queensland enrolment statistics.

The five means of data collection derived what Kincheloe and Berry (2004) described as a bricolage of methods and outcomes. The analysis of this eclectic collection of data required an equivalent rigour and complexity. We compiled the data and organized it into frames and codes in keeping with Goffman's (1959) seminal research approach. We wrote annotations and reflections in the margins and inserted audio notations into the audio and video recordings. Where we required word-for-word analysis, we transcribed portions of recorded interviews and inserted interpretations. We shared our interpretations with the children, school personnel and academic colleagues. Our research was conducted in the field, with children, in the natural school setting, which is highly variable and unpredictable. We sought robust research design through seeking and achieving thematic saturation, confirmation through the participants, and our consistent stance of being open to surprise. We discovered resonance between our frames and codes and the factors identified by Kilpatrick et al. (2003b) in their Figure - Relationship between indicators and level of maturity of the school-community partnership (Figure 1). We organised our presentation of the results and our interpretation according to this school-community partnership framework.

It is important to note that our research piloted the use of the Kilpatrick et al. (2003b) framework as an analytic tool for pedagogic sustainability of a rural school. We independently situated the indicators of different levels on the maturity 'wheel' segments and then discussed our rationales. While we situated the vast majority of factors on the same levels, where differences in our perceptions were encountered, we were quickly able to come to unanimity after discussing our reasons. The next challenge in developing this theoretical model of school-community partnership is to refine the measurement process.

\section{INSERT FIGURE 1 HERE}

Used with permission of the author.

\section{The School-Community Partnership Applied}

The factors of Kilpatrick, et al.'s (2003b) framework depicting school-community partnership were applied to organise the results of our school-based research. The first factor is an idea, problem, or opportunity for change. When the research was conducted, the first author was a visiting academic from a Canadian to an Australian university. The second author coordinated a visit to the respective small-rural school. The visit evolved into a formalised university-school partnership. The impetus for the research varied between key stakeholders. The first author was seeking epoch. She wanted to experience the culture of Australian rural schools. The second author believed that the university partnership would benefit the school. The principal wanted his pupils to experience the benefits of new educational technologies. The children who embraced the initiative from 
the onset (the figurative volunteers rather than the captives) explained that when the first author asked the children to tell her about their school and community, they reported realising that they 'didn't know much' and 'wanted to know.' In other words, ideas and opportunities inspired the relationship between the school and community, in this case operationally defined as university, but the motivation for change was unique to the research participants.

The second element of the framework is public relations. When the school-university partnership began to derive positive pedagogical benefit for the students, the stakeholders realised that the research initiative was an opportunity for public relations and thereby potential impact on the school enrolment figures. Five newspaper articles and two articles on the homepage of the university website were published about the research initiative. The second author initiated the first newspaper article to invite members of the community into the school to share their local knowledge. The other four newspaper articles were event reports, one about the visits from the local community members, and three about the final Celebration of Learning. The public relations department of the university posted two articles on the homepage of the website, reporting on the initiative and thereby acknowledging the university-school partnership.

Three months following the conclusion of the research initiative, the media releases catalysed registration of the critical numbers of students to ensure that the school maintained its two-room status. The parents registering their children identified the media reporting as bringing them to the school, and the teaching and learning processes described within the articles as the factor that decided the registration.

Decision making and community empowerment match are included by Kilpatrick, et al., (2003b) as the third and fourth elements of school-community partnership. The first author of this article presented the proposed research to the school principal and teachers, who in-principle approved participation. The principal applied for ethical clearance through Education Queensland. He then invited the Parents and Citizens' Association members to an information evening with the university researcher, following up individually with two families who had additional queries. All of the families signed informed consent for their children to participate. In other words, a representative of the university initiated the school-university partnership, whereupon the school administration took responsibility for the decision making, resulting in the creation of empowering conditions for the school and its community population including the university. Once the university-school partnership commenced, the principal and teachers supported their learners in taking a major role in the decision-making. The children chose their own research questions, their research methodology including planning their own excursions, and their means of sharing their research results.

The next factor in school-community partnership is shared vision. As described above, at the commencement of the research initiative, the stakeholders held compatible, yet distinct goals. As the experiential work commenced, the vision evolved as cohesive between all of the stakeholders. While the outcomes achieved each of these elements, stakeholder vision no longer focused on technology, cultural comparison, or enrolment 
boosting. The shared vision was teaching for active learning (Biggs \& Tang, 2007; Bransford, Brown \& Cocking, 2000; Kane, 2004). We were witness to, and part of, the compelling pedagogical shift of school culture. Research was assimilated into the epistemology of the teachers and the learners. The children's awareness of the vitality of their community, and the community's contribution to learning and teaching were heightened. Sustaining this pedagogical shift became our shared vision.

There is inherent risk in pedagogical shift and in opening the school environment to the greater community. Kilpatrick, et al., (2003b) identified risk taking as the next factor of school-community partnership. What risks did the stakeholders perceive? The school principal is accountable to the community on many levels. The principal of the case study school took the risk that the university-school partnership would enhance rather than distract from learning outcomes. As a principal of a small, rural school, he has developed a deep understanding of each child and a long-term relationship with each family. He has taught some families for twenty consecutive years. With a deep commitment to student centeredness, he needed to assess whether university-school partnership would promote desirable graduate attributes and acceptable scores on national standardised achievement tests. In opening the school to the community, including the university, he had to trust that the energies of the stakeholders would be for the good of the school and the children.

At the introduction to the research, some of the parents expressed concern for the safety and well being of their children because community engagement in the digital age means that once information and identification are released online, parents do not have control of the distribution. The parents' concerns were listened to and addressed, whereupon they took the risk of signing informed consent to a partnership between the school and the digital community.

Community resources are at the culminating point of Kilpatrick, et al.'s (2003b) diagram. Bringing the resources of the greater community into the school and fostering the community perception of the school as a resource were the strengths of the universityschool partnership. The initial question posed to the children was, what do you wonder about. In pondering this question, the children cast their gaze on their community. They reflected on the drought, and the flooding. They noted that an important social historic site was located just kilometres from the school, and they wondered about it. They contemplated how life had changed over the 122-year history of the school, and they wanted to know about the school graduates. When asked how they were going to discover this information, they naturally turned to the community.

The second author facilitated a small article in local newspaper advertising for people who were willing to come and share stories and information about the local community. The response from the community was tremendous. Approximately 20 people sent a positive RSVP. The majority of visitors to what we called a Tea and Talk were seniors, some of whom had graduated from the school many years before. The feedback on Tea and Talk overwhelmingly commended the bringing together of senior and child community members. The children were fascinated by the senior's stories, and were honoured to be the first to record and thus preserve their community's history. We also 
had two members of regional government council and representatives from professional divisions of government services such as catchments. People expanded their community membership to include the school and then remained involved with the children, school staff, and the research.

As a member of the community, the university contributed resources to the school initiative. A multimedia production team from the university joined the initiative, recording each event, excursion and exhibit, and then produced a movie. They turned the camera around, as one of the senior students on-camera interviewed the leader of the film crew about videography, as another student filmed. A university student from a digital videography course spent many hours with the children helping them learn digital video editing through producing their own movie. A graphics designer helped the children to develop a cartoon logo for their research, which they screen printed onto tee shirts. Graduate students came to demonstrate their research to the children. For example, one university researcher demonstrated an award winning device and process for measuring home water usage. A senior lecturer of arts in education worked alongside the principal and teachers to help the children construct four large plaster mountains that represented chronological periods of social history. This project component was particularly important for the students in the prep through year four class, as building the mountains engaged hands-on sensory experiential learning. Through our role as university researchers, we taught research skills and guided the students' process. The university arranged a mini-university excursion to the campus. The children experienced a session in a lecture theatre, were filmed in the television studio, and received an editing lesson in the suite.

The children planned three additional excursions to further experience their community. They walked a historical trail and re-enacted the first crossing through a range. They visited the local dry creek-bed and engaged in analysis of tracks and scats. They visited a local museum and had their faces painted with totems by an Aboriginal artist. Each excursion was led by community members with respective expertise rather than the school teachers. The university extended their resources to document the excursions on film.

Pedagogically, it is important to recognise that the resource exchange was reciprocal rather than one-sided. While the children benefitted enormously from the interpretation the community provided of their natural environment and history, and the children became inducted into the research process, they also generated knowledge and capacity within the community. Several of the seniors attending Tea and Talk commented that this event 'brought the community together again.' At Tea and Talk, the younger adults in attendance admitted that they too were lacking knowledge about their local community and history. The school principal had held this position for more than twenty years, but the children's research instigated his first knowledge of and visits to some of the historic sites in close proximity to the school. At the conclusion of the project, the children facilitated the resource of fellowship as the school hosted a Celebration of Learning to share the children's research findings. A school population of 32 children brought 125 people. Community members provided feedback that the children had generated 
knowledge thereby giving back to the community. Beyond this local distribution, the children's research outcomes were posted on the internet, thereby sharing information resources with the extended community.

The resource gain was also reciprocal between the school and university. The school resources became learning commodities for the university community. Within university subjects, the school initiative was presented and studied as a pedagogical exemplar. University academics presented papers at two scholarly conferences based on the research and process generated by the children, their teachers, and principal. New contributions to knowledge were also disseminated through multiple scholarly publications including this one. The children were among the first to use a new piece of podcast software. The software company used the children as beta testers to develop a more stable version, and rewarded the children with a site license for the software. With topics such as how to podcast, three technical articles were published in a professional educational technology magazine. Four months after the completion of the universityschool initiative, the university hosted a gala research exhibit, the resources for which were generated in partnership between the children, their teachers and principal, and university staff.

In summary, the results of the university-school partnership were framed through Kilpatrick et al.’s (2003) school-community process diagram. A partnership begins with the idea, problem, or opportunity for change, which in this case, started out as multifaceted and emerged as a shared vision for teaching for active learning within the distinctive context of a rural community. There are public relations advantages, which were initially oriented to benefitting the school through increased enrolment and then became reciprocal as the larger community benefitted from the media reports on their local school. The university was acknowledged as being engaged with their community partners and as a generator of scholarly research. The decision making with respect to participation in the project rested with the school principal, who supported empowering conditions such that the decision making within the project largely rested with the children (with support from their principal, teachers, and university researchers). There was substantive evidence that all stakeholders benefitted from their initial decision that the university-school partnership was worth the risk, as community resources were built by and for all participants.

\section{Interpretation}

Kilpatrick et al.'s (2003b) schemata of the 'relationship between indicators and the level of maturity of the school-community partnership' were chosen for interpretation of the research data because this framework facilitates prediction with respect to the sustainability of the rural school. Kilpatrick et al.'s research indicated that there was a reciprocal advantage to schools and communities with mature partnerships. Established relationship between schools and their greater communities substantially increased the likelihood of the school remaining open and the community existing as healthy and vital. 
Kilpatrick et al.'s (2003b) figure depicts three levels of maturity of the school-community partnership. The dark grey circle in the centre of the diagram represents early stages of partnership. The light grey circle depicts factors of a moderately mature partnership. The outer, white circle presents factors of late maturity, or in other words, a highly developed partnership.

We analysed our data according to each of the factors, seeking resonance with indicators of level of maturity. We did not confine our definition of community to the university. The university was one element of community in our researched school partnership, but this collaboration was temporary and analysis of this facet alone would be cross-sectional rather than long-term. While the school-university partnership informs the broader school-community partnership, it is important that our analysis defines community to include the stakeholders with whom the school needs a synergy for sustainability. For example, community must include members of the regional government, local newspaper editors, and the community association.

The first factor queries the source of the inspiration, idea, or problem. It reflects positively on the school-community partnership that the principal, teachers, children and their families were open to an idea that came from the university as an element of community. Kilpatrick et al. (2003b) indicated that school receptivity to community ideas positions them on the outer, or most mature, ring of the partnership level.

The second factor of maturity contrasts with the first in that the public relations efforts of the school and community were school-initiated event-based publicity, thereby placing the school-community partnership in the inner or early stages of maturity. The media were quite receptive to reporting on school events, but the school always initiated the contact. In order to sustain an active partnership between the school and community, it is important that the school listen for opportunities within the community, and that members of the community are inspired to think of their school as a resource, and one worth fighting for.

The third factor of decision-making is in the same inner (early) maturity circle as public relations. Decision-making was weighted towards the school. It was the school principal who had the authority to approve the university-school partnership. Realistically, it is doubtful that the decision-making can be shifted towards the community. It is the role of the principal to ensure that partnership activities are in the best interest of his students. It is the principal who is accountable to the children, the parents, and the school board. However, the community is accountable to society, and will hopefully make the broader decision to support their school as a vital component of community.

With respect to the factor of community empowerment match, the school-community partnership is in the central circle indicating moderate maturity. Within this initiative, the school demonstrated its ability to develop community capacity. The school became the meeting place on multiple occasions. Individual members and organisational groups of the community felt compelled to share their resources. Oral community history was 
recorded for prosperity. The Parents and Citizens' Association voted in new members and organised their first school open day.

The next factor on Kilpatrick et al.'s (2003b) schemata is at the heart of schoolcommunity partnership. The question is whether the vision of a dynamic, sustainable school is held only by key school stakeholders such as the principal, teachers, and some of the involved parents, whether this vision is shared by the school and community, or whether the school is part of the community's vision. Ultimately, rural schools will not have to fight so hard for survival because the community members will see the school as the essence of their community and ensure that this resource is safeguarded. Sadly, at this juncture, school sustainability is a vision of a small portion of this community, almost exclusively held by the key school stakeholders. For example, there are still many community members with primary school children who are bussing or driving their children long distances to the urban school rather than registering them at the local community school.

The school took a risk in opening themselves to partnership with the university. The school built on this risk to engage in what Kilpatrick et al. (2003b) described as opportunity moulding. For example, the principal engaged the resources of the first author to assist in crafting several project proposals. He also presented the educational technology components of the research initiative at a conference. The school agreed to help build the resources for a gala university exhibit and conference symposium with an eye to positive public relations for the school.

The culminating point of the school-community partnership framework is community resources. Once again the school falls within mid stage partnership. The universityschool initiative helped the children, teachers, and principal recognise and appreciate the value of members of the community as learning resources. Embracing diversity is an important prerequisite to community development. By bringing together generations and people from diverse domains of the community (e.g. farmers, government personnel, professionals) the community develops cohesiveness. Notably, through research into their own histories, the children grew an appreciation of Australia's Aboriginal heritage.

The community-school partnership was also in the middle level of maturity with respect to the community's valuing of the school as a learning resource. Many people provided feedback to the school staff and students that they learned a great deal about their community through the children's research. Not only did the children gain the respect of the community, but also esteem for the school as a centre of community scholarship was fostered.

In summary, the school-community partnership of the case study school may be pictured as a serpentine snake across the figure of maturity. The head of the snake rests within the outer circle, indicating maturity in school receptivity to community ideas. The snake curls its body to the centre of the circle with respect to both public relations (school-initiated event-based publicity) and decision-making (weighted towards school). The snake moves outward toward the middle once again in that the school contributed to the development 
of school capacity. Back to the centre or early maturity, the vision for school sustainability is that of the sub-sector of the school rather than larger community. The tail of the snake rests in middle maturity for the final two factors in that the school demonstrated high risk taking and opportunity moulding, and both the school and the community valued one another as learning resources.

\section{Conclusion}

Through the university-school partnership initiative, the school children, principal, teachers and members of the school Parents and Citizens' Association have become aware of the need to have the community involved with the school. Likewise, the community has voiced and demonstrated an enhanced commitment to their school as a vital component of their community. The school stakeholders particularly experienced the benefits of community involvement with teaching and learning. The students' curiosities were awakened when they became open to wonder in the local context of their own communities. Important relationships were fostered between the school children and staff and members of the broader community such as university educators, and councillors and professionals from local government. For example, excursions were particularly informative when led by community members who had expertise in the specific topic of inquiry combined with a passion inspired by their own local experiential histories. These professional community members inspired and mentored the children. One of the most moving relationships engendered through this partnership was between the children and the seniors of the community. The school became a place of fellowship where the generations of the community could come together and learn from one another. Members of the broader community expressed surprise and amazement at the accomplishments of the school children. They too learned from the children thus reinforcing the children's role as generators of knowledge and the future leaders within their community.

The school-community partnership varied in level of maturity across factors. Our assessment overall was that the school-community partnership is in the infancy to toddler stages. We learned through the children's inquiry into the school history that in the early years of the school there would not have been a question of whether the rural community needed their own school. A school within the community was a given. Conversation about school-community partnership would also have been nonsensical and interpreted as nonsense because there was no divide between what constitutes school and what constitutes community. Community meant school, and school was a vital part of the community, administered, staffed, and pupiled with community members. What happened? What changed? As described in the literature above, people are now willing and able to drive their children to schools outside their local communities because there is a perception that large-school, urban education is better. Perhaps the demise of the embedded school/community is also a symptom of lifestyle change. As described above, the greatest response to a call for community to bring their knowledge resources into the school came from the seniors. They were delighted to be 'back together' as one community, and the children were amazed to learn their community history through the stories of their elders. 
This school-community partnership initiative has awakened community members' minds to the importance of relationship in their local context. Many community members now realise and acknowledge that they have something to offer and a vital role to play in the education of the local children. As the vitality and creativity of this school's pedagogic journey evidences, it would be a tragedy if small, rural schools such as this one were to drop off the face of the Australian map. Based on our analysis of the case data, it is our prediction that the school-community teaching and learning relationship initiated through this project will continue to mature and thereby ensure the sustainability of the school and the community as embedded entities.

\section{References}

ABC Brisbane. (2008). The education department is considering closing two Lockyer Valley schools with a combined enrolment of 18 students. Online news report posted August 28, 2008. Retrieved September 26, 2008 from http://www.abc.net.au/news/stories/2008/08/28/2348962.htm?site=brisbane

Alvesson, M., \& Sköldberg, K. (2000). Reflexive methodology: New vistas for qualitative research. Thousand Oaks, CA: Sage.

Berg, B.L. (1995). Qualitative research methods for the social sciences. Toronto, ON: Allyn \& Bacon.

Biggs, J., \& Tang, C. (2007). Teaching for quality learning at university. Berkshire, England: Open University Press.

Bransford, J., Brown, A. \& Cocking, R. (Eds.) (2000). How people learn: Brain, mind, experience, and school. Washington DC: National Academy Press. Retrieved September 25, 2006 from http://www.nap.edu/books/0309070368/html

Ellis, C., Kiesinger, C., \& Tillman-Healy, L. (1997). Interactive interviewing: Talking about emotional experience. In R. Hertz (Ed.). Reflexivity and voice. (pp. 119149). Thousand Oaks, CA: Sage.

Emerson, R.M., Fretz, R.I., \& Shaw, L.L. (1995). Writing ethnographic fieldnotes. Chicago, IL: University of Chicago Press.

Goffman, E. (1959). The presentation of self in everyday life. Garden City, NY: Anchor Books.

Jones, G.W. (2004). The demography of disadvantage. Journal of Population Research, 21(2), 107-126. 
Kane, L. (2004). Educators, learners and active learning methodologies. International Journal of Lifelong Education, 23(3), 275-286.

Kilpatrick, S., Johns, S., \& Mulford, B. (2003a). Maturing schools-community partnerships: Developing learning communities in rural Australia. (CRLRA Discussion Paper Series ISSN 1440-480X). Launceston, Tas.: Centre for Research and Learning in Regional Australia.

Kilpatrick, S., Johns, S. \& Mulford, B. (2003b). Maturing school-community partnerships: Developing learning communities in rural Australia, Educational Research, Risks and Dilemmas, New Zealand Australian Association for Education Research Conference, 29 November- $3^{\text {rd }}$ December, Auckland. Retrieved 22 June 2009 from http://www.aare.edu.au/03pap/kil03489.pdf

Kilpatrick, S., Johns, S., Mulford, B., Falk, I., \& Prescott, L. (2002). More than an education: Leadership for rural school-community partnerships. A Report for the Rural Industries Research and Development Corporation. RIRDC Publication No. 02/055 RIRDC Project No. UT-31A. Kingston, ACT: RIRDC.

Kinash, S. \& Crichton, S. (2007). Digital Film-making as an Expression of Epistemological Stance. Peer Reviewed International Conference. $8^{\text {th }}$ Annual Advances in Qualitative Methods Conference. International Institute in Qualitative Methodology, September, 2007. University of Alberta, Banff Centre, Alberta.

Kincheloe, J.L., \& Berry, K.S. (2004). Rigour and complexity in educational research: Conceptualizing the bricolage. Berkshire, United Kingdom: Open University Press.

Marshall, C., \& Rossman, G. (1989). Designing qualitative research. Newbury Park, CA: Sage.

Miller, M. (2008). Queensland town battles to save school from closure. The Chronicle, September 10, 2008.

Morgan, R., \& Blackmore, J. (2007). How rural education markets shape parental choice of schooling: An Australian case study. Paper presented at AARE 2007 Conference Freemantle. MOR07547 Symposium 23, BLA07543

Moustakas, C. (1994). Phenomenological research methods. Thousand Oaks, CA: Sage.

Queensland Department of Education, Training and the Arts. (n.d.). Register of recent school openings, closures and name changes. Retrieved 26 September 2008 from http://education.qld.gov.au/directory/phone/index.html 
Reeves, E. B., \& Bylund, R. A. (2005). Are rural schools inferior to urban schools? A multilevel analysis of school accountability trends in Kentucky. Rural Sociology, 70, 360-386.

Smith, S. (29 April 2007). Investing in our future: An education revolution. Speech to Australian Labour Party National Conference. Retrieved online May 13, 2008 http://www.alp.org.au/media/0407/speedut290.php

Spradley, J.P. (1979). The ethnographic interview. Fort Worth, TX: Harcourt Jaovanovich.

van Manen, M. (1997). Researching lived experience: Human science for an action sensitive pedagogy. London, ON: Althouse.

van Manen, M. (2002). Writing in the dark: Phenomenological studies in interpretive inquiry. London, ON: Althouse.

Yang, R. K., \& Fetsch, R. J. (2007). The self esteem of rural children. Journal of Research in Rural Education. 22, 1-7. 